\title{
Implementation of Artificial Neural Network Method in Application Development to Measuring the Severity of Narcotics Substances in Blood
}

\author{
Dian Pratiwi \\ Trisakti University \\ Jl. Kyai Tapa No.1, Jakarta - Indonesia
}

\author{
Rika \\ Trisakti University \\ Jl. Kyai Tapa No.1, Jakarta - Indonesia
}

\begin{abstract}
There are various ways to detect the presence of compound drugs, such as heroin, cocaine, morphine in the human body. Either through a urine sample or blood sample. This study was undertaken with the aim to create a system that can detect the severity level of the effects of illegal drugs (narcotics) uses from the blood, with three different level ie minimal, moderate, and severe of the five compounds drugs and hemoglobin levels which contained from each blood sample. The fifth compound including diacetylemorphine, morphine, benzoylecgonine, amphetamine, and phencyclidine.

The working system that is in this software includes three essential processing, ie the normalization process of compound levels value in blood samples, training and testing process of Perceptron Neural Network. Initially each value of the five compounds level and level of hemoglobin which contained in blood transformation values to the interval $[0,1]$, then used as input values in the training process which will give the weights. These weights is then used in the testing process of new blood samples (non-learning data) to provide a prediction of the severity levels of narcotics.
\end{abstract}

From the test results with learning rate 0.3 , threshold value $0.5,2$ units of output units and 6 units of input units, this system has a success rate of $60 \%-100 \%$ from the test of a new blood sample data (non-learning data) and $100 \%$ for the training sample data (learning data).

\section{General Terms}

Artificial Neural Network, Pattern Recognition

\section{Keywords}

Drugs, Narcotics, Normalization, Perceptron Neural Network, Threshold

\section{INTRODUCTION}

Software is a phenomenon of the rapid development of the world information technology. Currently, software is one tool to get the solution easily and quickly. With that role, software has helped in various fields. One of them is by using artificial intelligence methods. Artificial intelligence in its effort mimicking human intelligence, such as artificial neural networks are modeled based on human neural network is widely used in several fields. As in the field of medicine, can help detect a wide range of symptoms or disease.

Narcotics are substances/drugs derived from plants or synthetic or semi-synthetic that can be lowered consciousness, loss of taste, reduce to relieve pain and can lead to dependence, such as opioids, cocaine, and marijuana. Some of the effects caused by the use of narcotics among hallucinogens, stimulants, and depressants.

With the rapid development of the world information technology, researchers made use of this opportunity to create software with Perceptron Neural Network methods. This software will be able to gauge the severity of drug levels of someone from the blood media, which results in the form of a percentage. The percentage is what will determine how severe the conditions of drug users and the appropriate treatment method.

\section{NARCOTICS}

Narcotics is a drug or a natural substances, synthetic or semisynthetic that can cause a decline in awareness, eliminate or reduce lost or pain and changes in consciousness which lead to dependence on these substances continuously [6]. An example which is famous narcotics such as marijuana, heroin, cocaine, morphine, amphetamines, and others.

The group of narcotics based on substances manufacture namely :

a) Natural Narcotics

Drugs and substances that can be used directly as a narcotics without need for fermentation, isolation, and other process first.

b) Synthetic Narcotics

This kind narcotics is requires the synthesis process for medical and research purposes as pain relievers or analgesics. Example of such amphetamines, methadone, dekstropropakasifen, deksamfetamin, etc.

c) Semi-synthetic Narcotics

Ie substances or drugs which produced by isolation, extraction, and other such as heroin, morphine, codeine, and others.

\section{PERCEPTRON NEURAL NETWORK}

Artificial Neural Network is defined as an information processing system that has characteristics resembling human nervous tissue. Neural network is created as a generalization of mathematical models of human understanding [1].

There are several types of neural network. However, almost all of them have the same components. Just as the human brain, neural networks are also composed of several neurons, and there is a connection between these neurons. 


\begin{tabular}{|c|c|c|c|c|c|}
\hline \begin{tabular}{|l} 
Input \\
dari \\
neuron \\
neuron \\
lain
\end{tabular} & $\stackrel{\text { bobot }}{\longrightarrow}$ & $\sum_{\text {Outpu }}$ & Fungsi Aktivasi & bobot & $\begin{array}{l}\text { Output } \\
\text { dari } \\
\text { neuron } \\
\text { neuron } \\
\text { lain }\end{array}$ \\
\hline
\end{tabular}

Fig 1: Neuron Structure of Artificial Neural Network [2]

The figure shows that the artificial neurons are actually similar to a biological neuron cells. Artificial neurons work in the same way also the biological neuron cells. Artificial neural networks in use can be divided into various architecture, and a simple neural network is described as follows :

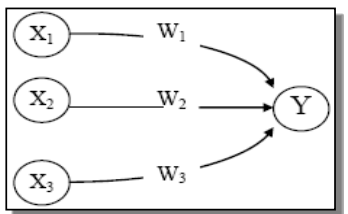

Fig 2: Simple Neural Netwok with One Ouput [3]

In the picture above, $\mathrm{Y}$ neurons receive input from $X_{1}, X_{2}$, and $X_{3}$ neurons, and $W_{l}, W_{2}, W_{3}$ are weighting of the connection between $X_{1}, X_{2}, X_{3}$ of the $Y$ neurons. The $Y$ _in input network on $Y$ neuron is the sum of the multiplication of the input neurons with each corresponding weighting, in which :

$$
\mathbf{Y}_{\text {in }}=\boldsymbol{\Sigma} \mathbf{X}_{\mathbf{i}} \cdot \mathbf{W}_{\mathbf{i}}
$$

Then $Y_{\text {_ }}$ in given activation function to produce $\mathrm{Y}$ neuron.

In ANN, learning is the process of establishing the configuration of weights prices of the network. This process aims to inputs that given to it will be responded through the weights so as to produce appropriate output or close to the target.

In general, the learning process of ANN can be categorized into two types of processes [5] :

\section{a) Supervised Training}

In this type, each input pattern has a target pattern, so that each input has a corresponding output pair

b) Unsupervised Training

In this training, the target vector is not required for the output so that there is no comparison to determine the ideal response

One of the reliable methods of Artificial Neural Network is Perceptron, which is a method of recognizing patterns with supervised learning methods. Its called reliable because Perceptron has a learning procedure that can produce convergent weights so as to follow the output is obtained in accordance with the targets of each input pattern. In other words, Perceptron is one of the Artificial Neural Network method that capable of recognizing patterns well.

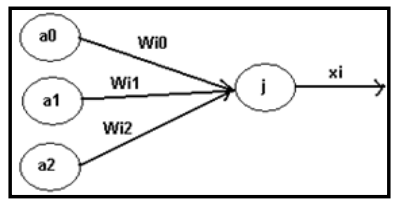

Fig 3 : Perceptron Processing Unit [3]

Perceptron is limited to two processors in a single layer coating weights (among others) that are able to adapt. In the picture above, the input units $(a 0, a 1, a 2)$ each connected via an interconnection weights (WiO, Wil, Wi2). The unit- weighted summation for the whole put it with following equation :

$$
\mathrm{sj}=\sum_{i=0}^{n} \text { ai. } w j i
$$

Where $W j i$ is the connection weight from $i$ unit to $j$ unit, and $a i$ is the input from $i$ unit.

Perceptron will test whether the weighted sum is above or below a predetermined threshold value, with the rules :

$$
\begin{gathered}
\text { If } \mathrm{Sj}>0 \text { then } \mathrm{xj}=1 \\
\text { If } \mathrm{Sj}<=0 \text { then } \mathrm{xj}=0
\end{gathered}
$$

Where $x j$ is the output value of $j$ unit

This output is then compared with the results (the target) is desired. The difference resulting from this comparison is used to change the weights on the network. Thus done repeatedly so that the resulting output that corresponds to the desired result with the formula of weight changes :

$$
W_{j i \_n e w}=W_{j i_{-} o l d}+C\left(t_{j p}-x_{j p}\right) a_{i}
$$

Where $C$ is the learning rate, $t(j p)$ is the desired output value of $j$ unit a given pattern $p$ in the input layer, $x(j p)$ is the output value that produced by the $j$ unit after a given pattern $p$ in the input layer, and $a(i)$ is the input from the first $i$ unit.

\section{RESULTS AND DISCUSSION}

\subsection{Compounds Narcotics Table}

From some of the research and information retrieval that researchers have done, it was concluded that compound drugs are taken to be the value of the input on the system are :

\section{Diacetylmorphine}

Known as diacetylmorphine or heroin, is a derivative of morphine, a substance made from the sap of the opium through a chemical process and including upioid group. Shaped like a fine white powder, sometimes shaped brown blob [9]. In the blood, heroin is then converted into monoacetylmorphine, with an average rate of heroin in the blood approximately 0.05 to $3.0 \mathrm{mg} / \mathrm{L}$ [7].

\section{Morphine}

Morphine is almost the same molecular structure with heroin, but has a euphoric effect is smaller than heroin. The average level of morphine in the blood approximately 0.2 to $2.3 \mathrm{mg} / \mathrm{L}$ [7].

\section{Benzoylecgonine}

Benzoylecgonine is a result of metabolic processes in the absorption of blood from the use of cocaine. Cocaine use on average $100 \mathrm{mg}$ of lead levels in the blood cocaine levels around 0.05 to $0.1 \mathrm{~g} / \mathrm{ml}$. Meanwhile, according to Baselt, cocaine levels that can harm the body is approximately $1-21 \mathrm{mg} / \mathrm{L}$ [4][7].

4. Amphetamine

Amphetamine is a compound found in the blood of the use of medication to reduce appetite and body stimulating drugs, such as Adderall and Dexedrine. Amphetamine levels commonly found in the blood is about 0.5 to 41 $\mathrm{mg} / \mathrm{L}$ [7]. 


\section{Phencyclidine}

Phencyclidine is a substance contained in the blood of the use of anasthetic drugs, neurotoxic. Blood levels in an average of about 0.3 to $25 \mathrm{mg} / \mathrm{L}$.

The fifth compound which will then be used by the researchers to be used as input values in the process of artificial neural network. From the fifth compounds, the researchers added another factor hemoglobin levels in the blood as an input value. This is because of several sources of information, most of drug users will experience anemia which in this case would reduce levels of hemoglobin in the blood. Normal levels of hemoglobin in the human body is between $12-14 \mathrm{~g} / \mathrm{dL}[10]$.

\subsection{Training of Artificial Neural Network}

In the training phase, the researchers used four blood samples that have been analyzed in the form of data that contain narcotic substances. Below is a table of data training :

Table 1. Perceptron ANN Training Data

\begin{tabular}{|l|c|c|c|c|}
\hline \multicolumn{1}{|c|}{$\begin{array}{c}\text { Narcotic } \\
\text { Subtances }\end{array}$} & \multicolumn{4}{|c|}{ Blood Samples } \\
\cline { 2 - 5 } $\begin{array}{l}\text { Diacetylmorphine } \\
(\mathrm{mg} / \mathrm{L})\end{array}$ & 0 & 0.5 & $\mathbf{2}$ & $\mathbf{4}$ \\
\hline Morphine (mg/L) & 0 & 0.3 & 0.9 & 2.5 \\
\hline $\begin{array}{l}\text { Benzoylecgonine } \\
(\mathrm{mg} / \mathrm{L})\end{array}$ & 0 & 0.1 & 5 & 15 \\
\hline $\begin{array}{l}\text { Amphetamine } \\
(\mathrm{mg} / \mathrm{L})\end{array}$ & 0.5 & 0.5 & 10 & 20 \\
\hline $\begin{array}{l}\text { Phencyclidine } \\
(\mathrm{mg} / \mathrm{L})\end{array}$ & 0.3 & 0.9 & 10 & 19 \\
\hline $\begin{array}{l}\text { Hemoglobin } \\
\text { (g/dL) }\end{array}$ & 12.5 & 12 & 11.7 & 10.4 \\
\hline \multicolumn{1}{|c|}{ Target } & Free & Minimal & Moderate & Severe \\
\hline
\end{tabular}

From table 1, the values of any narcotic subtances will be normalized or converted into the interval 0 to 1 . Due to the Perceptron ANN, the value of the input and output of a binary value, ie ' 0 ' or ' 1 '.
Training parameters of neural network :
a. Input unit $=6$ units
b. Output unit $=2$ units
c. Threshold $=0.5$
d. Learning rate $=0.1$ to 1.0
e. Tolerance $=0.01$ to 0.05

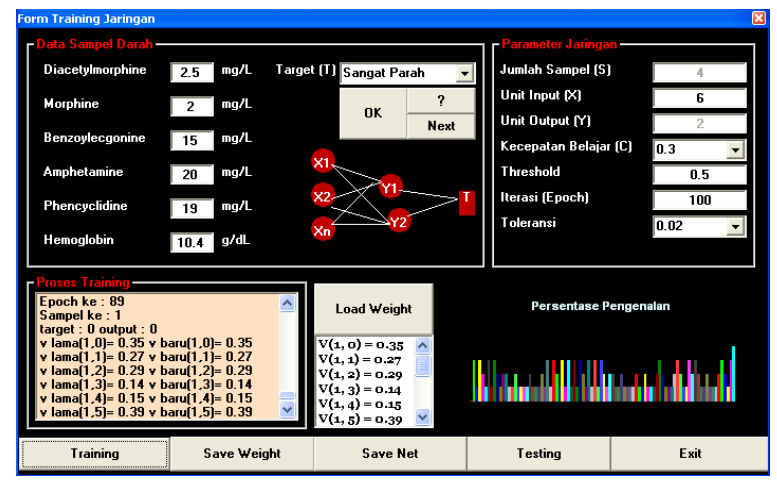

Fig 4 : Form Display of Perceptron ANN Training

From the results of the above training, the use of four blood samples (see Table 1), learning rate of 0.3 , iteration 100 epochs and tolerance of 0.02 , obtained a recognition percentage of $100 \%$ against of each sample were entered during the 89th iteration.

From the result of the recognition, will give corresponding weights for use in measuring the severity of narcotics. The resulting weights are : $\{0.35,0.27,0.29,0.14,0.15,0.39$, $0.01,0.38,-0.55,2.23,-2.18,-0.39,2.91,-0.7\}$. This weights is then saved and will be used in the testing process to a new blood sample data.

\subsection{Testing of Artificial Neural Network}

Here are the data tables of Perceptron ANN test results from 15 blood samples

Table 2. Perceptron ANN Testing Results Data

\begin{tabular}{|c|c|c|c|c|c|c|c|c|c|c|c|c|c|c|c|}
\hline \multirow{2}{*}{$\begin{array}{c}\text { Narcotic } \\
\text { Subtances }\end{array}$} & \multicolumn{15}{|c|}{ Blood Samples } \\
\hline & 1 & 2 & 3 & 4 & 5 & 6 & 7 & 8 & 9 & 10 & 11 & 12 & 13 & 14 & 15 \\
\hline $\begin{array}{l}\text { Diacetylmorphine } \\
(\mathrm{mg} / \mathrm{L})\end{array}$ & 0.07 & - & 0.05 & 0.5 & - & - & 1 & 0.8 & 1.5 & 1.3 & 2.0 & 2.0 & 2.7 & 2.5 & 2.0 \\
\hline Morphine (mg/L) & 0.3 & - & 0.5 & 1.1 & - & - & 0.9 & 1.2 & 1.3 & 1.2 & 1.8 & 2.0 & 2.0 & 1.9 & 2.29 \\
\hline $\begin{array}{l}\text { Benzoylecgonine } \\
(\mathrm{mg} / \mathrm{L})\end{array}$ & - & 1.5 & 0.9 & - & - & 10 & 11 & 10 & 10 & 5 & - & 10 & 9.8 & - & - \\
\hline $\begin{array}{l}\text { Amphetamine } \\
(\mathrm{mg} / \mathrm{L})\end{array}$ & 0.6 & 5 & - & - & 10 & 5 & 6.9 & 7 & 12 & 19 & 20 & 28 & - & 30 & - \\
\hline $\begin{array}{l}\text { Phencyclidine } \\
\text { (mg/L) }\end{array}$ & - & - & - & 3 & - & 3 & 1.5 & - & 4 & 5.8 & 10.9 & - & 23.5 & 20.9 & 21 \\
\hline $\begin{array}{l}\text { Hemoglobin } \\
(\mathrm{g} / \mathrm{dL})\end{array}$ & 12 & 11.7 & 11.9 & 12 & 12.5 & 10 & 11.2 & 11 & 12.2 & 11.7 & 11.7 & 10 & 11 & 10.9 & 10.8 \\
\hline *Target & Min & Min & Min & Min & Min & Mod & Mod & Mod & Mod & Mod & $\mathrm{Sev}$ & $\mathrm{Sev}$ & $\mathrm{Sev}$ & $\mathrm{Sev}$ & $\mathrm{Sev}$ \\
\hline *Ouput & Min & Free & Min & $\mathrm{Sev}$ & Free & Free & Mod & Mod & $\mathrm{Sev}$ & $\mathrm{Sev}$ & $\mathrm{Sev}$ & $\mathrm{Sev}$ & $\mathrm{Sev}$ & $\mathrm{Sev}$ & $\mathrm{Sev}$ \\
\hline
\end{tabular}




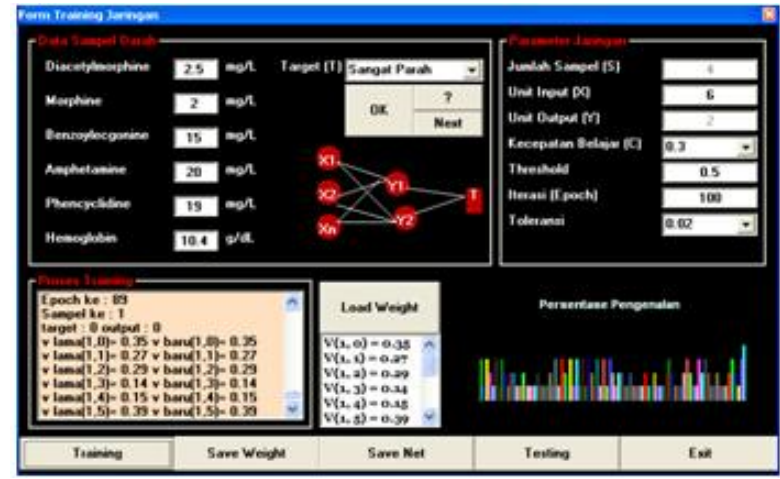

Fig 5 : Form Display of Perceptron ANN Testing

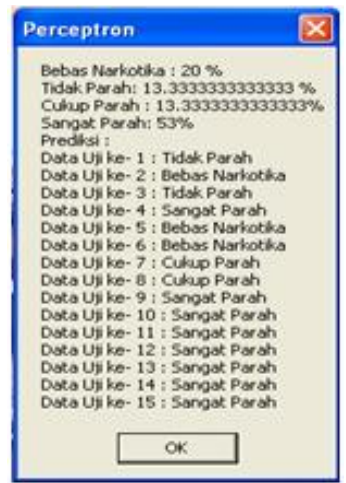

Fig 6 : Detail Display from The Test Results of 15 Blood Samples

From the test results of 15 blood samples above, in table 2 can be seen that there are measurement errors of narcotic levels as much as 6 samples. This could be due to the samples used in the training sample is only 4 pieces, and still to little to make a network more intelligent in measuring the drug levels. However, from the results of tests on 15 samples, 9 samples were proved correct in determining the severity of drug levels, and it is proved that the use of Perceptron method in neural network gives quite good results with a success rate of $60 \%$.

\section{CONCLUSION}

The conclusion from the results of this research are :

1. Perceptron method in Artificial Neural Network is one method that can be used to create measurement and detection applications with quite good success rate, because more than $50 \%$ of the blood samples were tested to measure their severity properly
2. The use of 0.5 threshold value, 0.3 learning rate constant, the epoch of 100 iterations, the number of output units is 2 , and 6 input units indicates that the resulting weights can be used with either the testing process with a success percentage of $60 \%$ and $40 \%$ failures of 15 blood samples were tested

3. To obtain appropriate weights required training trials repeated, because the weights are generated from training will determine the level of success in the testing phase

\section{REFERENCES}

[1] Andry H. 2004. Studi Kasus Mengenai Aplikasi Multilayer Perceptron Neural Network Pada Sistem Pendeteksi Gangguan (IDS) Berdasarkan Anomali Suatu Jaringan, Institut Teknologi Bandung. Bandung.

[2] Arief H. 2006. Jaringan Syaraf Tiruan Teori dan Aplikasi, Penerbit ANDI, Yogyakarta

[3] Ary N, Satryo PH, Wahyono. 2006. Pengenalan Huruf Berbasis Jaringan Syaraf Tiruan Menggunakan Algoritma Perceptron. Http //www.scrib.com/doc/13826849/pengenalan-hurufberbasis-jaringan-syaraf-tiruan-menggunakan-algoritmaperceptron. Yogyakarta : Universitas Gadjah Mada

[4] Andre, Fachtitah, Grisye, Hendry. 2010. Kematian karena Narkotika dan Obat-Obat Halusinogen. www.freewebs.com/halusinogen.

[5] Benyamin K, Renny I,R. 2001. Pengembangan Sistem Pengenal Objek 3 Dimensi Menggunakan Jaringan Syaraf Tiruan Dengan Lapisan Tersembunyi Berbentuk Silinder, Jurnal Ilmu Komputer \& TI

[6] Iriansyah B.M, 2007. Teknik Pengidentifikasian Fitur Wajah dan Sidik Jari Menggunakan Jaringan Syaraf Tiruan Perceptron

[7] Nita, Michael, Irma, dkk. 2005. Toksikologi Forensik www.freewebs.com/toksikologiforensik.

[8] Wim P, Yulian P,. 2007. De Perceptron Aplikasi Market Basket Analysis Berbasis Web Menggunakan Perceptron, Universitas Gadjah Mada, Yogyakarta

[9] Heroin. 2010. www.rsko-jakarta.com

[10] Hasil Tes Lab Normal. 2010. Yayasan Spritia. www.aidsinfonct.org. 